\title{
The Legal Protection Against Child Marriage in Indonesia
}

\author{
Rizky Irfano Aditya a,1,* Lisa Waddington ${ }^{\mathrm{b}, 2}$ \\ ${ }^{a}$ Faculty of Law, Maastricht University, Netherlands \\ ${ }^{b}$ Faculty of Law, Maastricht University, Netherlands \\ 1 rizkyirfano-law@maastrichtuniversity.nl *; ${ }^{2}$ lisa.waddington@maastrichtuniversity.nl \\ * corresponding author
}

\section{ARTICLE INFO}

\section{Article history}

Received: January 20, 2021

Revised: November 2, 2021

Accepted: November 4, 2021

\section{Keywords}

Legal Protection;

Child Marriage;

Indonesia;

\begin{abstract}
Every child is a human being who possesses the right to justice, freedom, and opportunity to develop regardless of nationality, race, religion, or skin complexion. These rights of children are guaranteed by the United Nations Universal Declaration of Human Rights. However, its reality indicates otherwise, as children are often the victims of exploitation. One of the worst such kinds of child exploitation is child marriage. This study aims to analyze the legal protection against child marriage in Indonesia. This research is conducted through the normative analysis of various written sources. This study concludes that the Indonesian Child's Act even has a provision that stipulates the obligation of parents to prevent early marriages. However, the law is somewhat effective in Indonesia. Unfortunately, the fatal flaw is the low-threshold provision that enables parents to request dispensation for early marriage. This shatters all the efforts to eliminate child marriage. Thus far, the Indonesian Government also has shown its reluctance to ever amend discriminatory provisions in the Indonesian Marriage Act related to the practice of child marriage despite numerous recommendations from the Convention on the Elimination of Discrimination against Women.
\end{abstract}

This is an open access article under the CC-BY 4.0 license.

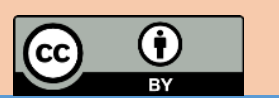

\section{Introduction}

Every child is a human being who possesses the right to justice, freedom, and opportunity to development regardless of their nationality, race, religion or the complexion of their skin. These rights of children are guaranteed by the United Nations Universal Declaration of Human Rights. Children are generally thought of as the most important assets of a nation. Thus, they should be protected from harm. However, its reality indicates otherwise, as children are often the victims of exploitation. One of the worst cases of child exploitation is child marriage (Muhammad \& Tummala, 2021).

Child marriage is also referred to as early marriage or forced marriage, where most victims are not engaged in the arrangement willingly. The term 'child marriage' itself is defined as a formal or customary union that involves children under the age of eighteen. The Elimination of Discrimination against Women (CEDAW) - CRC Joint General Recommendation states that child marriage occurs whenever one of the parties to a marriage is under 18. According to statistical data from UNICEF, 
child marriage takes place the most in developing countries. The issue of child marriage has been addressed by several international conventions, including the International Covenant on Economic, Social and Cultural Rights (ICESCR) and the CEDAW (Kiconco \& Nthakomwa, 2018).

For instance, in regard to Article 12 of the ICESCR, the Committee on Economic, Social and Cultural Rights suggests the need to adopt measures to abolish harmful traditional practices affecting the health of children, including early marriage. Article 16 (2) of the CEDAW is even more direct, it states that the betrothal and marriage of a child should not have legal effect and urges state parties to specify a minimum age in their legislations. Likewise, although the CRC does not, mention child marriage, its Article 24 (3) explicitly urges state parties to abolish any harmful traditional practices prejudicial to the health of children (Rönsch, 2020).

Due to their nature, international covenants are not binding if not ratified by a state as expressed in Article 11 of the Vienna Convention on the Law of Treaties. In this regard, as a ratifying country to both the ICESCR and Women's Convention, the Republic of Indonesia is indeed bound by a series of obligations deriving from both documents. Those obligations include the duty to protect children, especially girls, from the practice of child marriage. To this end, national legislation in Indonesia is known to provide several protections against child marriage. For example, the minimum age standard for marriage, which is stated in Article 7 of the Indonesian Marriage Act (1974), has been set at 19 years old for males and 16 years old for females. Another provision of protection against child marriage can be found in the Indonesian Child's Act (2014); Article 27 of this Act mandates parents to prevent the underage marriage of their children.

Given how many legislative protections Indonesian children are supposedly offered, the number of child marriages in Indonesia should be relatively low. Surprisingly, however, data shows that the rate of child marriage in Indonesia is the second highest among the ASEAN countries. A researcher found that in 2016, as many as 22.000 girls in Indonesia, ranging from 10 to 14 years old, were married. The organization, National Population and Family Planning of Indonesia, noted that in 2017 the number of underage marriages increased for people aged 15 to 19. Another fact suggests that child marriages in Indonesia mainly occur in rural regions. The Regional National Population and Family Planning Office in Northern Sulawesi (Borneo) stated that North Sulawesi has the highest rate of child marriage in Indonesia. In addition, most victims of child marriage are young girls who have been seen as a burden to their families (Sahovic \& Eriamiatoe, 2020).

The Indonesian Central Statistics Bureau stated in an interview that child marriage in Indonesia is caused by various factors, including poverty, religious belief, and social stigma. Ahmad Hilmi, a project manager of Rumah Kita Bersama, added that the presence of complacent state officers who allow such marriages to take place also plays a significant role in the problem. The Chief of the National Population and Family Planning Office, Surya Surapaty, believes that child marriage can destroy the mental state of a child because children are not mature enough to properly enter marriage (Islam, 2019).

She also believes that marrying at a very young age could affect reproductive health, leading to a high risk of death during pregnancy or childbirth. The fact that child marriage is still common in Indonesia despite opposing legislation is rather peculiar. It raises questions about the effectiveness of the law in the country. Based on the circumstances outlined above, this thesis will discuss how effective the legal protections against child marriage in Indonesia (Foussiakda \& Kasherwa, 2020).

\section{Research Method}

To answer the research question, this research is conducted through the normative analysis of various written sources. This discussion hopes to understand better about how well the laws related to the abolishment of child marriage have been implemented at the domestic level (Svevo-Cianci et al., 2011). Primary sources used in this research include international conventions, documents from human rights treaty bodies such as CEDAW and CRC regional level treaties, and Indonesian domestic laws related to protection against child marriage. Secondary sources such as textbooks, research journals, offline and online articles will also be consulted. This study will use both deductive and inductive methods to grasp the application of specific laws in the situation of child 
marriage in Indonesia. In the end, this paper will focus on attempting to analysis many major problems in the implementation of laws related to child marriage in Indonesia to achieve strong insight into the problem statement (Raj et al., 2009).

\section{Results and Discussion}

\subsection{Factors Contributing to Child Marriage in Indonesia}

The practice of child marriage in Indonesia has reached a critical state, endangering the future of Indonesian children and women. The following section discusses several main factors related to child marriage in Indonesia. One of the most significant rationales for underage marriage is unfortunate economic, social, and cultural situations. Poverty plays quite a prominent role in promoting child marriage. For instance, a poor girl in Senegal is four times more likely to marry as a child than a similar girl from an affluent household. Poverty forces low-income families in Indonesia to face the bitter reality that they will not be able to meet many primary needs for their children, such as access to education (Tobin \& Cashmore, 2020).

Public schools in Indonesia are prohibited from charging any student for facilities, uniforms, or textbooks. Regardless, some schools still charge students for certain facilities, doing so undetected by the authorities. As a result, many Indonesian children who come from low-income families have to drop out of school. A boy who has dropped out of school is usually told to work alongside his parents. Contrarily, many girls in a similar situation are exploited by their families, being sold to wealthier men who want to marry them. Being married to more prosperous men does not make the girl or her family wealthier. Such girls often end up being abused by their husbands or divorced within weeks of marriage (Sugue-Castillo, 2009).

The thousands of islands in Indonesia create a very diverse culture in terms of social systems and norms. People in particular parts of Indonesia, for example, country, like West Sumatra, follow the matriarchal social system. In West Sumatera, most of the time, women get to choose the men they marry. Even so, a large part of traditional Indonesian societies accepts patriarchal systems. In those societies, women are treated unequally to men and are made to live by rules created by men (Spence \& Lan, 2021).

The patriarchal social system in most of Indonesia creates a poor paradigm for women. For example, in many regions, it is socially unwise and somewhat unacceptable for a woman to leave her house after dark, while men are allowed free passage regardless of the hour. In respect to marriage, a woman could be labeled as "too old" if they were single for too long while a man would not have to worry about such a label. This paradigm burdens the girls of Indonesia to rush into marriage. In South Kalimantan, people tend to think that girls should be married before she is 20 years old. Religion also plays a substantial role in bolstering child marriage in Indonesia. As citizens of one of the biggest Muslim countries globally, the majority of people in Indonesia are somewhat conservative (Warria, 2017). Religious beliefs have generally been used as a justification for child marriage. Marriage is seen as a tool to prevent sexual promiscuity, which is forbidden by the dominant religion. Many traditional families in Indonesia still rely on marriage in this fashion. Again, girls become the victim of vicious social prejudice, hurry into getting married without their consent.

The Cambridge Online Dictionary interprets corruption as dishonest behavior perpetrated by people in positions of power. That definition fits what has been occurring in Indonesia perfectly. The country suffers from an abysmal international reputation regarding corruption. It has been ranked 91 out of 176 countries on the Corruption Perception Index 2016 by Transparency International.

The corruption in Indonesia also contributes to the on-going practice of child marriage. Despite the minimum age set by the Indonesian Marriage Act 1974, many underage people continue to get married. It is quite common in Indonesia to falsify someone's age so that he or she appears to meet the legal requirement. Legally, data fabrication by governmental institutions is considered as an illegal act in Indonesia. Any foul act by a civil servant in the interest of personal gain is prohibited; moreover, the perpetrator can be charged under Article 12 (e) of the Indonesian Anti-Corruption 
Act. Though Indonesian authorities have tried to reduce such fraudulent practices, many instances remain undetected.

\subsection{Impact of Child Marriage in Indonesia}

The following sections discuss some of the damaging effects child marriage causes its victims. During their childhood, children are supposed to spend their time studying at school and playing with their friends. Such joyous and enlightening moments will be remembered as a child grows into an adult and will affect their ultimate character as a result. Marriage deprives children of their childhood. Once they are married, children become responsible for carrying out the domestic chores, of which they have little or no knowledge at all. Psychologically, most young brides do not match the maturity of their husbands. Undoubtedly, this difference often leads to conflict in their families. Most of the time, such marriages end in divorce, and such girls are also more likely to become widows at a younger age than average(Gage, 2013).

UNICEF reports that a girl under the age of 15 years old is five times more likely to die during pregnancy and delivery than a woman in her 20 . This data is undebatable proof that child marriage could risk the health of a young woman. Married girls are more likely than unmarried girls to become infected with STDs, particularly HIV and HPV. According to the Indonesian Ministry of Health report, there were about 18.422 people infected with HIV/AIDS in Indonesia. That number has increased rapidly as in 2016, there were 65.826 people treated with ARV and were categorized as people with HIV or AIDS. Although at the moment, early marriage is not the primary cause of HIV in Indonesia, the elimination of child marriage could help to suppress the expansion of the HIV/AIDS epidemic in Indonesia(Mirzaee et al., 2021).

Forcing immature female genital organs to receive penetration before they are fully matured can cause trauma, cervical cancer, and widespread infection. Furthermore, the baby of a pregnant girl can be in danger as well, as he or she may potentially suffer from birth defects or disease. This increased risk of morbidity and mortality is often due to the young mother's poor nutrition, physical and emotional immaturity, lack of access to proper social and reproductive services, and higher risks of infectious disease(Biswas et al., 2019).

Child marriage is still practiced in Indonesia, especially in the rural areas where most of the victims are under-aged girls. Several factors are contributing to child marriage in Indonesia. The first of these is poverty that forces many families to give up education for their children. Second, a common gender stereotype assumes that a girl needs less education than a boy because the former is only meant to be a housewife. Third, corrupt registry officers assist in enabling a child marriage to take place. Child marriage brings harm to its victims. First, child marriage can cause trauma and mental disturbances for victims. Second, the victims of child marriages are more likely to suffer from a series of illnesses, like HIV/AIDS or other STDs. They are also prone to fatality when giving birth.

\subsection{The Available Legal Protections Against Child Marriage in Indonesia}

The Universal Declaration of Human Rights is an international document agreed to be the foundation of international human rights. It is the essential reference point for a cross-cultural discussion on human freedom and dignity in the world today. By its nature, this declaration is not binding. However, many of the provisions within this document have become incorporated into customary international law, which is binding on all states. In relation to the prohibition of child marriage, the declaration is undoubtedly favorable. Article 16 (1) of the UDHR affirms that those people who have the right to marry, regardless of their race, nationality, or religion, are men and women. In addition, Article 16 (2) of the same document recognizes that a marriage shall be entered into only with the free and full consent of the intending spouse.

The second part of Article 16 of the UDHR emphasizes the element of "consent", which is very much linked to the concept of protection against child marriage. Consenting marriages require the fulfilment of three necessary conditions: they must be informed, competent and voluntary. In relation to child marriages, most children would not fully understand the responsibility acquired after becoming married. Such children simply follow the will of their parents. Minors lacking 
mature appreciation of the salient information in a contract or complex situation cannot enter into legally binding agreements(Kudo, 2021).

Through the ICESCR, several provisions in the UDHR regarding economic, social, and cultural rights may become binding to the states that choose to ratify it. This Covenant was one of the first international treaties that substantially dealt with the issue of child marriage. Article 10 of this document recognizes the right to marriage based on the condition of free and full consent. In addition, General Comment No. 16 of the CESCR sets out that state party's obligation to ensure equal rights between men and women to choose if, whom and when to marry. Indonesia was the only signatory to the International Covenant on Economic, Social and Cultural Rights. Even still, in 2005, the Indonesian Government finally ratified the Covenant and established the ratification titled, Indonesian Act about the Ratification of International Covenant on Economic, Social, and Cultural Rights No. 11 of 2005 . Today, Indonesia is legally bound by obligations from the ICESCR, and it is essential that the country actually follows through on those obligations (Riad \& Forden, 2021).

Another essential tool from the Covenant is the available remedy derived from the Optional Protocol to the International Covenant on Economic, Social and Cultural Rights. Through this protocol, victims whose economic, social and cultural rights become harmed may communicate their complaint to a responsible committee body. Unfortunately, such a mechanism is not yet available in Indonesia because Indonesia is not yet a signatory to the Optional Protocol. Ultimately, however, Indonesia is a party to the ICESCR, which means it shall eventually embrace the obligations of this Covenant. The CEDAW was a response to the need for an international treaty guarding specific human rights for women. In 1975, the United Nations had its first Women's Conference, discussing the particular human rights problems facing women. Four years later, in 1979, the General Assembly adopted the Women's Convention. The present Convention also has its own treaty body called the Committee on the Elimination of Discrimination against Women that monitors state parties' compliance (Efevbera \& Farmer, 2021).

A Joint General Comment by Committee on the Elimination of Discrimination against Women together with Committee on the Rights of the Child provides one finite definition of child marriage. This Joint General Comment states that child marriage is considered to be forced marriage given that one or both parties of such marriages do not express their full, free and informed consent. The document also notes that child or forced marriage may affect the life of the child and risk their enjoyment of the right to freedom of movement (Tisdall \& Cuevas-Parra, 2020).

The CEDAW plays a considerable role in the protection against child marriage because, as aforementioned, girls and women are often victims of child marriage. Article 16, in particular Sections 1, affirm that state parties guarantee the equality of men and women in the right to enter marriage, and the same rights in entering marriages only with free and full consent. Indeed, a girl is often reluctant to object when asked to marry a man by her parents. Young girls are less capable of understanding the implications of long-term decisions and do not have the full autonomy and independence nor the mental and emotional maturity required for such decision making. Despite the fact that the freedom of speech is guaranteed by the Indonesian Constitution, some traditional societies still tend to think that a girl should obey her parents without question. This is why the equal right to enter marriage with free and full consent is important when considering child marriage, especially given the traditional way of thinking of most Indonesian parents(Lee \& Svevo-Cianci, 2011).

Article 16, Section 2, of the CEDAW reaffirms the validity of a marriage contracted by minors. This part of the present convention is quite explicit in prohibiting early marriage. It states that a betrothal and marriage contracted by children cannot have a legal effect. More importantly, this provision also gives conception to the idea that state authorities should act to prevent child marriages. Actions in this regard are defined to include all normal regulatory options, including legislation to specify a minimum age for marriage and requiring every marriage to be registered with an official registry. The CEDAW also has a body and complaint procedure through its optional protocol. This optional protocol provides two reporting mechanisms: the individual complaint procedure and the inquiry procedure. Albeit that Indonesia is not yet signatory to it, the country is still bound by obligations from the treaty. To that extent, the Committee on the Elimination of Discrimination against Women has expressed its concern about the continuing child marriage 
problem in Indonesia. The committee has also demanded the country criminalise individuals who force a child to marry (Wismayanti et al., 2019).

One year after the independence of Indonesia came the Indonesian Marriage Act of 1946, which was also the first marriage act produced by the postcolonial Indonesian Government. This Act only interpreted marriage under Islamic law, and in 1973 there was a widespread protest by the Indonesian Catholic Fraction about it. The revised Indonesian Marriage Act of 1974 has been regulating marriage in a more general fashion since then. The current Indonesian Marriage Act 1974 contains a provision that implies child marriage prevention it mentions a minimum age for marriage The term 'minimum age for marriage' refers to the age at which a person is allowed by law to marry (Arifiani et al., 2019). Comparatively, the Joint General Recommendation by CEDAW and CRC indicates that child marriage occurs when one of the parties is under 18 years old. It means that, in principle, the minimum age to marry should be 18 years old. However, Article 7 (1) of the Indonesian Marriage Act determines that the minimum age of a person who is allowed to marry is 19 years old for a man and 16 years old for a woman. There is, however, one exception when looking at Article 7 (1) because Article 7 (2) of the Indonesian Marriage Act provides that, in cases where the bride or the groom is below the minimum age, their parents can inquire for dispensation to the court.

This shows the inconsistency of Article 7 (1) of the Indonesian Marriage Act. Clearly, it is a step backwards for protections against child marriage. Indonesian girls are still in a vulnerable position despite there being national legislation that specifies the supposed minimum age for marriage. The Indonesian Child's Act is an essential instrument with the rationale that children are inherently unable to protect themselves. Furthermore, it is also the manifestation of the principal Human Rights Act in Indonesia. Article 58 (1) of the Act No. 39 of 1999 proclaims that every child has the right to legal protection from all kinds of mental and physical violence, abandonment, and sexual harassment.

The Indonesian Child's Act is one of the most crucial weapons for fighting the practice of child marriage. It contains several articles that are sensitive to the issue of child marriage, like ones specifying the minimum age of a person who is to be considered a child and the obligations of parents in protecting their child's rights. To this end, Article 1 (1) says that a person is considered as a child at any time he or she is before 18 years old. Logically, when there is a marriage where one of the parties is under 18 years old then, that constitutes child marriage. Another interesting trait of the Indonesian Child's Act is its provisions for the obligations of parents. Article 26 (1) of the Act states that parents have the sole responsibility to prevent and forbid under-aged marriage. Clearly, parents have a significant role in preventing child marriage as most of the time, and they are the ones who have control over their children. Yet, such provisions contradict Article 7 (2) of the Indonesian Marriage Act 1974, which allows child marriage with dispensation from the court (Petroni et al., 2019).

\subsection{Analysis on the Effectivity of Legal Protection Against Child Marriage in Indonesia}

Hypothetically, the State possesses an inherent responsibility to respect, protect and fulfill the human rights of its citizens. The victims of human rights violations may complain to governmental authorities and seek redress. This is the point of departure as to why the effectiveness of legal protection against child marriage in Indonesia mainly lies in implementing domestic law. Such an idea is provoked in as much as Indonesia has not ratified the Optional Protocol of CEDAW that provides direct access to remedy for women becoming victims of human rights violation. The previous discussion has already acknowledged that the minimum age for marriage has been specified in the Indonesian Marriage Act as advised by Article 16 (2) of the CEDAW. According to Article 7 (1) of the Indonesian Marriage Act, the minimum age to marry for women is 16 years old and 19 years old for men. In addition to that, Article 26 (1) of the Indonesian Child's Act also affirmed an obligation for parents to prevent the early marriage of their children. Unfortunately, the minimum age to marry for women in Indonesia is not yet in line with the standard set out in the Joint General Recommendation by CEDAW and CRC, which is 18 years old.

Regardless, the inconsistency between the General Recommendation and the Marriage Act does not give an exact answer about the effectiveness of the legal protection against child marriage in 
Indonesia. In fact, by integrating the minimum age to marry into national legislation, Indonesian Government has demonstrated their dedication to eliminating child marriage. This age specification is already consistent with the obligation from Article 16 (2) of the CEDAW regarding the prohibition of any betrothal or marriage of a child. Practically, according to Article 7 (1) of the Marriage Act, no parent should allow a daughter who is younger than 16 years old to marry. It shows that the legal protection against child marriage in Indonesia is not fully malfunctioning. The implementation of this law is clear in Indonesia, the Marriage Act is the ultimate reference to all of the practices in marriage in the country. In other words, at least from this perspective, the legal protection against child marriage is not completely ineffective.

Another massive issue with the legal protection against child marriage in Indonesia can be recognized from the Indonesian Marriage Act itself. Article 7 (2) of the Marriage Act imposes leeway for early marriage. The Article states that the parents can propose a dispensation to the court in case one of the parties to a wedding is under the minimum age. The dispensation for early marriage in Indonesia can be obtained by requesting it through religious courts for Muslims, and the District Courts for non-Muslims. In principle, the request for such dispensation can either be granted or denied by the Court. According to one of Indonesia's Tribun News, the number of the requests for early marriage dispensations keeps increasing each year. In fact, from 2013 to 2015, the percentage of requests for early marriage dispensations increased $15-70 \%$ each year.

One example of a Court Decision granting a dispensation for early marriage comes from the Religious Court of Ambarawa Regency. A decision letter, number 0010/Pdt.P/2014/PA.Amb., permitted an early marriage with the following considerations. A snippet from the Court's decision above shows that the threshold for the judges to grant a dispensation is very low. The judges in that particular case only considered simple general facts. For example, the judges believed that the bride was ready to be a good housewife on the grounds of a written statement only. They did not explicitly consider whether there may have been an underlying right of the bride that may have been violated and the reasoning behind why the bride made her statement. Taking the above-discussed points into consideration, is it clear that there are serious problems in the effectiveness of Indonesian legislation against child marriage. The possibility for dispensation to allow child marriage is apparently contradictory to the International Conventions like CEDAW and the ICESCR. Moreover, CESCR suggested that the Indonesian Government attempt to prevent child marriage from ever to happen, to ensure the effectiveness of the legal control of child marriage. The possibility for a dispensation for child marriage is a blunder that ruins all the possible goodwill commitment of the Indonesian Government to eradicate child marriage from the country.

\section{Conclusion}

Based on the discussions above, the research questions outlined in chapter One can be answered with the following conclusions How effective is the legal protection against child marriage in Indonesia. The matter of the effectiveness of legal protection against child marriage in Indonesia is mainly based on how well the law related to this issue is implemented nationally. Hence it can be deduced that the law related to the eradication of child marriage in Indonesia is not effective yet. However, some rules that are vital in fighting child marriage are quite well implemented in Indonesia. They are already inserted in the domestic legislation. For instance, Indonesian Marriage Act has specified a minimum age to marry for men and women, which is in favor of the ICESCR and CEDAW. The Indonesian Child's Act even has a provision that stipulates the obligation of parents to prevent early marriages. If considering these facts alone, this research would conclude that the law is somewhat effective in Indonesia. Unfortunately, the fatal flaw is the low-threshold provision that enables parents to request dispensation for early marriage. This shatters all the efforts to eliminate child marriage.

\section{References}

Arifiani, S. D., Handayani, S. A., Baumont, M., Bennouna, C., \& Kusumaningrum, S. (2019). Assessing large-scale violence against children surveys in selected Southeast Asian countries: 
A scoping review. Child Abuse \& Neglect, 93, 149-161. https://doi.org/10.1016/j.chiabu.2019.05.005

Biswas, R. K., Khan, J. R., \& Kabir, E. (2019). Trend of child marriage in Bangladesh: A reflection on significant socioeconomic factors. Children and Youth Services Review, 104, 104382. https://doi.org/10.1016/j.childyouth.2019.06.017

Efevbera, Y., \& Farmer, P. (2021). 'It is this which is normal' A qualitative study on girl child marriage and health in conakry, Guinea. Social Science \& Medicine, 273, 113762. https://doi.org/10.1016/j.socscimed.2021.113762

Foussiakda, A. C., \& Kasherwa, A. C. (2020). The challenges affecting foster care in a "failedstate" context: Case of the SEDI child protection network in South-Kivu Province, Democratic Republic of Congo. Children and Youth Services Review, 116, 105217. https://doi.org/10.1016/j.childyouth.2020.105217

Gage, A. J. (2013). Child marriage prevention in Amhara Region, Ethiopia: Association of communication exposure and social influence with parents/guardians' knowledge and attitudes. Social Science \& Medicine, 97, 124-133. https://doi.org/10.1016/j.socscimed.2013.08.017

Islam, M. S. (2019). An assessment of child protection in Bangladesh: How effective is NGO-led Child-Friendly Space? Evaluation and Program Planning, 72, 8-15. https://doi.org/10.1016/j.evalprogplan.2018.09.003

Kiconco, A., \& Nthakomwa, M. (2018). Marriage for the 'New Woman' from the Lord's Resistance Army: Experiences of female ex-abductees in Acholi region of Uganda. Women's Studies International Forum, 68, 65-74. https://doi.org/https://doi.org/10.1016/j.wsif.2018.02.008

Kudo, Y. (2021). Does criminalizing discriminatory cultural practices improve women's welfare? A simple model of Levirate marriage in Africa. Economics Letters, 199, 109728. https://doi.org/10.1016/j.econlet.2021.109728

Lee, Y., \& Svevo-Cianci, K. (2011). General Comment no. 13 to the Convention on the Rights of the Child: The right of the child to freedom from all forms of violence. Child Abuse \& Neglect, 35(12), 967-969. https://doi.org/10.1016/j.chiabu.2011.10.001

Mirzaee, Z., Maarefvand, M., Mousavi, M. T., Pourzand, N., Hossienzadeh, S., \& Khubchandani, J. (2021). Stakeholders' perspectives on girls' early marriage in Maneh and Samalqan, Iran. Children and Youth Services Review, 122, 105900. https://doi.org/10.1016/j.childyouth.2020.105900

Muhammad, T., \& Tummala, P. (2021). The progress in child protection 30 years after the CRC and the impact of ISPCAN. Child Abuse \& Neglect, 119, 105134. https://doi.org/10.1016/j.chiabu.2021.105134

Petroni, S., Das, M., \& Sawyer, S. M. (2019). Protection versus rights: age of marriage versus age of sexual consent. The Lancet Child \& Adolescent Health, 3(4), 274-280. https://doi.org/10.1016/S2352-4642(18)30336-5

Raj, A., Saggurti, N., Balaiah, D., \& Silverman, J. G. (2009). Prevalence of child marriage and its effect on fertility and fertility-control outcomes of young women in India: a cross-sectional, observational study. The Lancet, 373(9678), 1883-1889. https://doi.org/10.1016/S01406736(09)60246-4

Riad, G., \& Forden, C. (2021). "If we didn't talk, we would be like ostriches burying our heads in the sand": Attitudes toward sexuality, gender, and sex education among child protection 
social workers in Egypt. Children and Youth Services Review, 129, 106205. https://doi.org/10.1016/j.childyouth.2021.106205

Rönsch, H. (2020). Effectiveness of laws and policies governing permissive parenting in pursuit of the reduction of severe child abuse in Germany. Children and Youth Services Review, 119, 105510. https://doi.org/10.1016/j.childyouth.2020.105510

Spence, N., \& Lan, N. T. T. (2021). Family sustainability and child protection in Vietnam. Children and Youth Services Review, 122, 105884. https://doi.org/10.1016/j.childyouth.2020.105884

Sugue-Castillo, M. (2009). Legal outcomes of sexually abused children evaluated at the Philippine General Hospital Child Protection Unit. Child Abuse \& Neglect, 33(3), 193-202. https://doi.org/10.1016/j.chiabu.2008.09.004

Svevo-Cianci, K. A., Herczog, M., Krappmann, L., \& Cook, P. (2011). The new UN CRC General Comment 13: "The right of the child to freedom from all forms of violence"-Changing how the world conceptualizes child protection. Child Abuse \& Neglect, 35(12), 979-989. https://doi.org/10.1016/j.chiabu.2011.09.006

Tisdall, E. K. M., \& Cuevas-Parra, P. (2020). Challenges for children's participation: Child activism for ending child marriage. Children and Youth Services Review, 108, 104568. https://doi.org/10.1016/j.childyouth.2019.104568

Tobin, J., \& Cashmore, J. (2020). Thirty years of the CRC: Child protection progress, challenges and opportunities. Child Abuse \& Neglect, 110, 104436. https://doi.org/10.1016/j.chiabu.2020.104436

Sahovic, N. V., \& Eriamiatoe, P. (2020). Effectiveness of the convention on the rights of the child in realization of the right to a remedy for child victims of violence in Africa. Child Abuse \& Neglect, 110, 104307. https://doi.org/10.1016/j.chiabu.2019.104307

Warria, A. (2017). Forced child marriages as a form of child trafficking. Children and Youth Services Review, 79, 274-279. https://doi.org/10.1016/j.childyouth.2017.06.024

Wismayanti, Y. F., O'Leary, P., Tilbury, C., \& Tjoe, Y. (2019). Child sexual abuse in Indonesia: A systematic review of literature, law and policy. Child Abuse \& Neglect, 95, 104034. https://doi.org/10.1016/j.chiabu.2019.104034 